\title{
反射ルーバーまたはベネチャンブラインドのある空からの 直射日光を含む昼光による室内照度の計算理論
}

$\begin{array}{lllll}\text { 正会員 } & \text { 宿 } & \text { 谷 } & \text { 昌 } & \text { 則* } \\ \text { 正会員 } & \text { 木 } & \text { 村 } & \text { 建 } & \text { 一**⿰冫⿰亅⿱丿丶丶 }\end{array}$

\section{1.はじめに}

昼光光源として直射日光を除外し，天空光のみを対象 とした昼光照明では，屋外の天空光照度の変動に影響さ れずに，室内の明るさを表す指標として昼光率が定義さ れ ${ }^{1)}$ ，これを用いて天空光による室内照度が計算されて きた。乙かしながら，昼光率には直射日光の影響及び効 果が含まれていないので，これを用いて直射日光を含む 昼光による室内照度の計算を行うことはできない。そこ で，筆者等は，屋外の水平面直射日光照度の変動を受け ずに，直射日光によって得られる室内照度を表す指標と して直射日光率を定義する必要を感じ，これと昼光率と を併用することにより室内照度を表寸試みを行った2。 ところが，直射日光率には，地物で反射した直射日光の 影響が含まれていないので, 直射日光率と昼光率とを用 いる計算理論では，地物で反射した直射日光の影響を考 慮することができない。

本報では, 直射日光率と尽光率とを用いた室内照度の 表示方法をさらに発展させ，地表面で反射した直射日光 の影響をも考慮し得るようにするために，昼光率を天空 光による成分と地表面で反射した昼光による成分とに区 別して表示する方法を提案する。応用例として，空面に 反射ルーバーもしくは日照調整用のベネチャンブライン ドが設置された場合について直射日光, 天空光及び地表 面で反射した昼光によって得られる室内照度の試算を行 った結果を示し，従来の昼光率を用いた計算理論による 場合と比較検討した結果について論じる。なお, 本研究 の一部は既報した ${ }^{3), 4) 。 ~}$

2. 直射日光率, 天空光率, 地表面反射昼光率による 室内照度の表示

図一1 に示すように，晴天時に注直射日光，天空光， 地表面で反射した昼光の 3 種類がある。高層建築の中間 階の室で, 空面前は十分に開けており, 対向建物の影響 を無視し得るものとする。まず，屋外の直射日光照度に 影響されずに，㨁射日光による室内の明るさを表す指標

* 早稲田大学理工学研究所 奖励研究生 - 工博

***早稲田大学 教授・工博

（昭和 57 年 2 月 7 日原稿受理日，討論期限昭和 58 年 2 月末日）

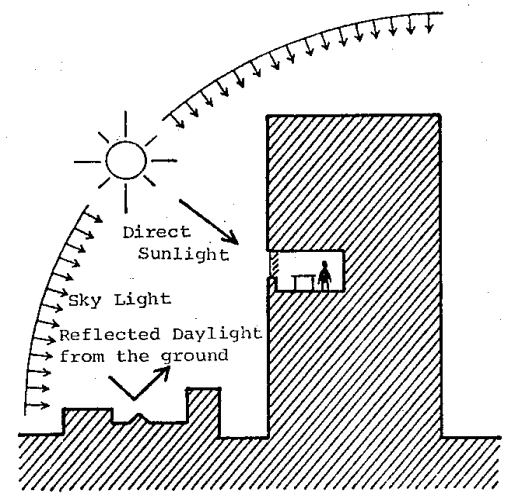

Fig. 1 Three Natural Light Sources under the Clear Sky Condition

として直射日光率 $D_{F}[$ 一一 を次式のよらに定義する2。

$$
D_{F}=\frac{E_{P D}}{E_{D H}}
$$

ただし，

$E_{P D}:$ 直射日光によって得られる室内照度 [lx]

$E_{D H}:$ 水平面直射日光照度 $[\mathrm{lx}]$

地表面では，直射日光，天空光の双方が拡散反射するも のとすれば，地表面で反射した直射日光と天空光とは同 一の光源とみなすことができる。そこで，従来の昼光率 から，地表面で反射した天空光の影響を除外したものを 天空光率 $S_{F}[-]$ と呼び, 次式のように定義する。

$$
S_{F}=\frac{E_{P S}}{E_{S H}}
$$

ただし，

$E_{P S}:$ 天空光によって得られる室内照度 $[1 \mathrm{x}]$ （地表面で反射した天空光によるものは含 まない)

$E_{S H}:$ 水平面天空光照度 $[\mathrm{lx}]^{* 1}$

また，地表面で反射した昼光*2の影響を受けずに，地表 面で反射した昼光による室内の明るさを表す指標として 地表面反射昼光率 $R_{F}[-]$ を次式のように定義する。

\footnotetext{
*1 水平面天空光照度は建築学会用語の全天空照度と同一であ る。本論では, 水平面直射日光照度に対応する語として全 天空照度の代わりに水平面天空光照度を用いることにし た。

*2 直射日光と天空光の和。
} 


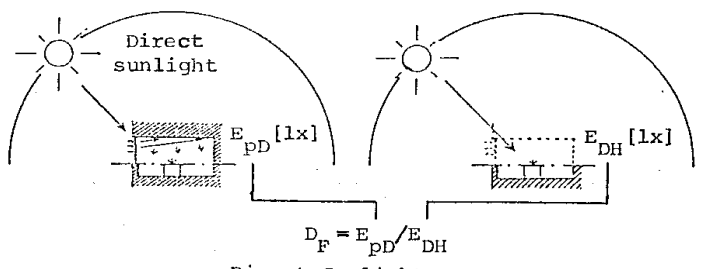

Direct Sunlight Factor

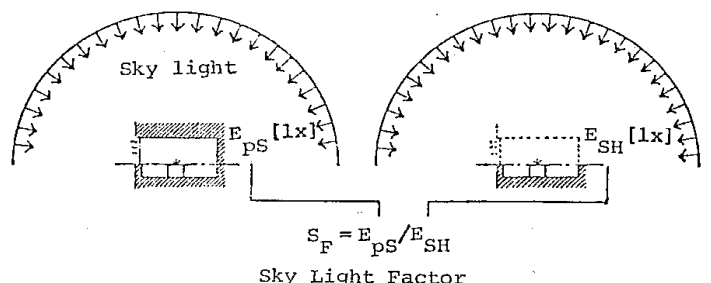

Reflected Daylight Factor $\mathrm{R}_{\mathrm{F}}=\mathrm{E}_{\mathrm{pR}} / \mathrm{M}_{\mathrm{RH}}$

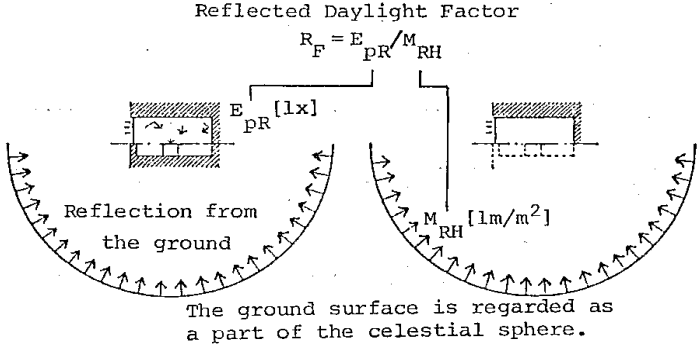

Fig. 2 The Concept of $D_{F}, S_{F}, R_{F}$

$$
R_{F}=\frac{E_{P R}}{M_{R H}}
$$

ここで,

$$
M_{R H}=\rho_{L G}\left(E_{D H}+E_{S H}\right)
$$

ただし，

$E_{P R}$ : 地表面で反射した昼光によって得られる室 内照度 $[\mathrm{lx}]$

$M_{R H}:$ 地表面の光束発散度 $\left[\mathrm{lm} / \mathrm{m}^{2}\right]$

$\rho_{L G}:$ 尽光に対する地表面反射率 [一]

図一2 に直射日光率，天空光率，地表面反射昼光率の 概念を示す。(1)〜 (3) 式加ら明らかなよらに，直射目 光率，天等光率，地表面反射昼光率はそれぞれ水平面直 射日光照度, 水平面天空光照度, 地表面の光束発散度に 対するそれぞれ直射日光，天空光，地表面反射昼光によ って得られる室内照度の比であり，従来から用いられて いる昼光率と同样の考え方である。

直射日光率, 天空光率, 地表面反射昼光率を用いれ ば，室内作業面上の任意の点 $p$ の照度は次式のように表 すことができる。

$$
E_{P}=D_{F} \cdot E_{D H}+S_{F} \cdot E_{R H}+R_{F} \cdot M_{R H}
$$

ただし， $E_{P}$ : 室内作業面上の任意点 $p$ の照度 $[\mathrm{lx}]$ 是天時には， $E_{D H}=0$ となるから，(5) 式は次のように 書き换えることができる。

$$
E_{P}=\left(S_{F}+\rho_{L G} \cdot R_{F}\right) E_{S H}=d_{F} \cdot E_{S H}
$$

（6）式は，天空光率に地表面反射率と地表面反射昼光率 との積を加えたものが昼光率 $d_{F}$ に等しくなることを示 于。

3. 反射ルーバーによる直射日光率, 天空光率, 地表

\section{面反射昼光率}

反射ルーバーは，既報礼に提案したよらにスラットの 表面が鏡面反射性で，裹面がグレア源とならないような 拡散反射性のスラット集合体であり，室内の天井面に直 射日光を渞入して昼光照明を行うための装置とする。

\section{1 直射日光率}

反射ルーバーによって室内に導入された直射日光は， 天井面，側壁面，奥壁面に入射する汃ら，天井面，側壁 面，奥壁面に生じる直射日光受照部完完全拡散 2 次光源 と考光れば，直射日光率核次式のように表すことができ $b^{* 1}$ 。

$$
\begin{aligned}
D_{F}= & \frac{\tau_{D} \rho_{S} c_{L} a \sum_{k=1}^{3} \rho_{w k} f_{k} \cos \theta_{k}}{\sin h} \\
& +\frac{\tau_{D} \rho_{S} c_{L} a\left(l_{1} \bar{\rho}_{1}+l_{2 D}\right) \bar{\rho}_{2}}{\left(1-\bar{\rho}_{1} \bar{\rho}_{2}\right) \sin h}
\end{aligned}
$$

ここで,

$$
\begin{gathered}
l_{1 D}=\frac{1}{A_{w}} \sum_{k=1}^{3} \rho_{w k} F_{k w} A_{k} \cos \theta_{k}=\sum_{k=1}^{3} \rho_{w k} F_{w k} \cos \theta_{k} \\
\ldots \ldots \ldots \ldots \ldots \ldots \ldots \cdots \cdots \cdots \cdots \cdots(8) \\
l_{2 D}=\frac{1}{A_{w}} \sum_{k=1}^{3} \rho_{w k}\left(1-F_{k w}\right) A_{k} \cos \theta_{k} \cdots \cdots \cdots(9) \\
F_{k w}=\frac{A_{w}}{A_{k}} F_{w k}=\frac{1}{A_{k}} \int_{A_{w}} f_{k} d A_{w} \cdots \cdots \cdots \cdots(10)
\end{gathered}
$$

ただし，

$\tau_{D}$ : 直射日光に対する空ガラスの透過率 [一]

$\rho_{S}$ : 反射ルーバーの鏡面スラット面の反射率 [一-

$c_{L}$ : 反射ルーバーに入射する直射日光の中で天井 面方向に向加割合 $[\text { 一 }]^{23}$

$a$ : 反射ルーバーで反射された值射日光によって 実際に，天井面，側壁面及び奧壁面に生じる 直射日光受照部面積の, 反射ルーバーのある 空面全体から直射日光が天井面, 側壁面及び 奥壁面に入射した場合の直射日光受照部面積 に対する比 $[\text { 一 }]^{2>}$

$\rho_{w k}$ ：直射日光受照部 $k$ の反射率 $[$ 一 $](k=1$ : 天 井面, $k=2$ : 側壁面, $k=3$ : 奥壁面)

$f_{k}$ : 直射日光受照部 $k$ による作業面上の点 $p$.の 立体角投射率 [一]

$\theta_{k}:$ 直射日光受照部 $k$ への入射角 $\left[{ }^{\circ}\right]$

$l_{1 D}, l_{2 D}:$ 直射日光受照部より発散する全光束の中で作 業面の下方，上方に入射する割合 [一]

$\bar{\rho}_{1}, \bar{\rho}_{2}$ : 室内の作業面より下方，上方の等洒反射率 $[-]$

$A_{w}:$ 作業面面積（床面積） $\left[\mathrm{m}^{2}\right]$

*1 既報2では，室内側壁，奥壁の直射日光受照部を無視し， 天井面全体を等輝度完全拡散光源とした場合について反射 ルーバーによる直射日光率を導いたが，本報では，太陽位 置の変化に伴ら天苏面直射日光受照部の偏りや室内側壁, 奥壁の直射日光受照部も考慮した結果を示す。以下，既報 の式を簡易式，本報の式を精密式と呼ぶことにする。 
$F_{k w}$ ：直射日光受照部 $k$ より発散する光束の中で 作業面に 入射する光束の割合 $(k=1$ : 天井 面, $k=2:$ 側壁面； $k=3:$ 奥壁面)

$A_{k}$ : 反射ルーバーのある空面全体から直射日光 が，天井面，側壁面，奥壁面に入射した場合 の直射日光受照部 $k$ の面積 $\left[\mathrm{m}^{2}\right]$

(7) 式で右辺第 1 項は 2 次光源による直射日光率の直接 成分を; 第 2 項恃作業面切断公式による直射日光率の間 接成分を示す。 $f_{1}$ 及び $F_{1 w}$ の值は，作業面上の点 $p$ に 対して平行な長方形，直角三角形による立体角投射率を 用いて， $f_{2} ， f_{3}$ 及び $F_{2 w}, F_{3 w}$ の值は点 $p$ に対して垂 直な長方形に上る立体角投射率のほかに，文献 5）に示 した基本的な三角形光源による立体角投射率を組み合わ せることによって得ることができる。

\section{2 天空光率}

図一3 のような反射ルーバーのある空面による天空光 率は，天空輝度を一様とすれば，スラットを二次元的に 考えることによって次式のように表すことができる。

$$
\begin{aligned}
S_{F}= & \tau_{d}\left(U_{1 l} L_{1 S}+U_{2 l} L_{2 S}+U_{S l}\right) \\
& +\frac{f_{S \tau_{d}} A_{l}\left(l_{1} \bar{\rho}_{1}+l_{2 S}\right) \bar{\rho}_{2}}{A_{w}\left(1-\bar{\rho}_{1} \bar{\rho}_{2}\right)}
\end{aligned}
$$

ただし

$\tau_{d}:$ 拡散光に対する空ガラスの透過率 $[$ - $]$

$U_{1 l}, U_{2 l}$ : 反射ルーバーのスラット面 1 , 面 2 による 作業面上の点 $p$ の立体角投射率 $[$ -

$L_{1} S, L_{2} S$ : 一様天空輝度に対する反射ルーバーのスラ ット面 1 , 面 2 の輝度の比 $[-]$

$U_{S l}$ : 反射ルーバーのスラット間から見える空に よる作業面上の点 $p$ の立体角投射率 $[-]$ $f_{S}$ : 灾空による㲅面の立体角投射率 [一]

$A_{l}$ : 反射ルーバーのある空の面積 $\left[\mathrm{m}^{2}\right]$

$l_{1} S, l_{2 S}$ : 反射ルーバーのある梥面に入射寸る天空光 に対する作業面の下方，上方に入射する光 束の割合 $[$ 一 $]$

(11) 式で， $U_{1 l}, U_{2 l}, U_{S l}$ 注文献 2) に示した立体角投 射率 $U_{0}(x), U_{h}(x, \hat{o}), U_{t}(x) * 1$ を組み合方せ，次の上 らな場合分けをすることによって表すことができる。図 一3 を参照して $\pi / 2<\beta$ とすると，
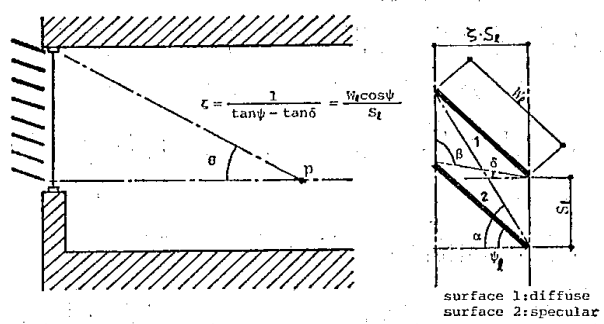

Fig. 3 Relationship between an Arbitrary Point p on the Work Plane and Reflective Louvers

*1 文献 2) では, $U_{0}(x), U_{h}(x, \delta), U_{t}(x)$ をそれぞれ $U_{0 x}$ ， $U_{h x}, U_{t x}$ と表した。 $\alpha<\theta$ のとき，

$$
\begin{aligned}
& U_{1 l}=\frac{U_{v}}{U_{0}(\theta)}\left\{U_{0}(\theta)-U_{0}\left(\psi_{l}\right)-U_{t}(\alpha)\right\} \\
& U_{2 l}=\frac{U_{v}}{U_{0}(\theta)}\left\{U_{0}\left(\psi_{l}\right)-U_{h}\left(\phi_{l}, \delta\right)\right\} \\
& U_{S l}=\frac{U_{v}}{U_{0}(\theta)}\left\{U_{h}\left(\psi_{l}, \delta\right)+U_{t}(\alpha)\right\} \cdots \cdots . . .
\end{aligned}
$$

$\phi_{l}<\theta \leqq \alpha$ のとき,

$$
\begin{aligned}
& U_{1 l}=\frac{U_{v}}{U_{0}(\theta)}\left\{U_{0}(\theta)-U_{0}\left(\phi_{l}\right)-U_{t}(\theta)\right\} \\
& U_{2 l}=\frac{U_{v}}{U_{0}(\theta)}\left\{U_{0}\left(\phi_{l}\right)-U_{h}\left(\psi_{l}, \delta\right)\right\} \ldots . . \\
& U_{S l}=\frac{U_{v}}{U_{0}(\theta)}\left\{U_{h}\left(\phi_{l}, \delta\right)+U_{t}(\theta)\right\} \ldots \ldots . .
\end{aligned}
$$

$\delta<\theta \leqq \psi_{\imath}$ のとき，

$$
\begin{aligned}
& U_{1 l}=0 \\
& U_{2 l}=\frac{U_{v}}{U_{0}(\theta)}\left\{U_{0}(\theta)-U_{h}(\theta, \delta)\right\} \\
& U_{S l}=\frac{U_{v}}{U_{0}(\theta)} U_{h}(\theta, \delta)
\end{aligned}
$$

$0 \leqq \delta$ のとき,

$$
\begin{aligned}
& U_{1 l}=0 \cdots \\
& U_{2 l}=U_{v} \\
& U_{S l}=0 .
\end{aligned}
$$

ここで,

$$
\begin{aligned}
& \alpha=\tan ^{-1}\left(\frac{S_{l}+W_{l} \sin \phi_{l}}{W_{l} \cos \phi_{l}}\right) \\
& \delta=\tan ^{-1}\left(\frac{W_{l} \sin \phi_{l}-S_{l}}{W_{l} \cos \phi_{l}}\right) \\
& \beta=\tan ^{-1}(-\cot \delta)
\end{aligned}
$$

ただし，

$U_{v}$ : 反射ルーバーのある空西全体による作業面 上の点 $p$ の立体角投射率 $[$ 一 $]$

$\beta \leqq \pi / 2$ のときは (12) (23) 式で $\delta=0$ と扔く。

また， $L_{1 S}, L_{2 S}, l_{1}, l_{2}$ の值は，鏡面反射性と拡散 反射性のスラット面が組み合わされた場合に生じる鏡面 反射性スラット面による虚像の效果を考慮した相互反射 の方程式を解くことによって得ることができる6)。

\section{3 地表面反射昼光率}

反射ルーバーのある空面による地表面反射杳光率は， 地表面輝度を一様とすれば，天空光率の場合と同様にし $\tau$

$$
\begin{aligned}
R_{F}= & \tau_{d}\left(U_{1 l} L_{1 R}+U_{2 l} L_{2 R}\right) \\
& +\frac{f_{g} \tau_{d} A_{l}\left(l_{1 R} \bar{\rho}_{1}+l_{2 R}\right) \bar{\rho}_{2}}{A_{w}\left(1-\bar{\rho}_{1} \bar{\rho}_{2}\right)}
\end{aligned}
$$

ただし

$L_{1 R}, L_{2 R}$ ：一様地表面輝度に対寸る反射ルーバーのス ラット面 1 ，面 2 の輝度の比 [一]

$f_{g}:$ 地表面による空面の立体角投射率 $[$ 一

$l_{1 R}, l_{2 R}$ : 反射ルーバーのある空面に入射する地表面 反射昼光に対す尚作業面の下方，上方に入 
射する光束の割合 [一]

(24) 式中の $L_{1 R}, L_{2 R}, l_{1 R}, l_{2 R}$ は (11) 式中の $L_{1 S}$, $L_{2 S}, l_{1} S, l_{2 S}$ と同様にして求めることができる6”。

4. ベネチャンブラインドによる直射日光率, 天空光 率, 地表面反射昼光率

ベネチャンブラインドは直射日光を遮るために用いら れるが，スラット面で反射された直射日光は，天空光に 比べて室内照度全体にかなり大きな影響を及ぼすことが 少なくない。また，反射ルーバーの効果をべネチャンブ ラインドそ比較するには，べネチャンブラインドにも同 一の計算理論を適用する必要がある。ここでは，簡単の ために, ベネチャンブラインドを表面, 裹面ともに完全 拡散反射性を有する平板スラットの集合体と仮定した場 合の直射日光率; 天空光率, 地表面反射昼光率について 論じる。

\section{1 直射日光率}

ベネチャンブラインドのある空面による直射日光率 は，スラットを二次元的に考光，図一6 b) に示すよう にスラット裏面を面1とすれば,

$$
\begin{aligned}
D_{F}= & \frac{\tau_{D} U_{1 b} B_{1 D} \cos h \cos \gamma}{\sin h} \\
& +\frac{\tau_{D} A_{b}\left(b_{1 D} \bar{\rho}_{1}+b_{2}\right) \bar{\rho}_{2} \cos h \cos \gamma}{A_{w}\left(1-\bar{\rho}_{1} \bar{\rho}_{2}\right) \sin h} \\
= & \frac{\tau_{D} U_{1 b} B_{1 D}}{\tan \phi}+\frac{\tau_{D} A_{b}\left(b_{1 D} \bar{\rho}_{1}+b_{2 D}\right) \bar{\rho}_{2}}{A_{w}\left(1-\bar{\rho}_{1} \bar{\rho}_{2}\right) \tan \phi}
\end{aligned}
$$

ここで, $\tan \phi=\tan h / \cos r$

ただし，

$U_{1 b}$ : ベネチャンブラインドのスラット面 1 によ る作業面上の点 $p$ の立体角投射率 [一]

$B_{1 D}:$ ベネチャシブラインドのある空面に入射す る直射日光照度に対するスラット面 1 の光 束発散度の比 $[$ 一 $]$

$A_{b}:$ ベネチャンブラインドのある葖の面積 $\left[\mathrm{m}^{2}\right]$

$b_{1 D}, b_{2 D}:$ ベネチャンブラインドのある空面に入射す る直射日光に対する作業面の下方, 上方に 入射する光束の割合 [一]

\section{$\phi:$ みかけの太陽高度 $\left[{ }^{\circ}\right]^{* 1}$}

(25) 式から明らかなように，ベネチャンブラインドの ある空面による直射日光率は, み各けの太陽高度の関数 として表すことができる。

\section{2 天空光率}

ベネチャンブラインドのある言面による天空光率は， 反射ルーバーのある空面と同様にして,

$$
S_{F}=\tau_{d}\left(U_{1 b} B_{1}+U_{S b}\right)+\frac{f_{S} \tau_{d} A_{b}\left(b_{1} \bar{\rho}_{1}+b_{2 S}\right) \bar{\rho}_{2}}{A_{w}\left(1-\bar{\rho}_{1} \bar{\rho}_{2}\right)}
$$

\footnotetext{
*1 太陽高度 $h$ の壁面法線方向の成分，文献 12)
}

ただし。

$B_{1 S}$ : 一様天空輝度に対するべネチャンブライン ドのスラット面 1 の輝度の比 $[-]$

$U_{S b}$ : ベネチャンブラインドのスラット閒から見 える空による作業面上の点 $p$ の立体角投射 率 $[$ - $]$

$b_{1 S}, b_{2 S}$ : ベネチャンブラインドのある空面に入射す る天空光に対する作業面の下方，上方に入 射する光束の割合 $[-]$

\section{3 地表面反射寔光率}

ベネチャンブラインドのめる空面による地表面反射昼 光率も反射ルーバーのある空面の場合と同様にして，

$$
R_{F}=\tau_{d} U_{1 b} B_{1 R}+\frac{f_{g} \tau_{d} A_{b}\left(b_{1} \bar{\rho}_{1}+b_{2 R}\right) \bar{\rho}_{2}}{A_{w}\left(1-\bar{\rho}_{1} \bar{\rho}_{2}\right)}
$$

ただし

$B_{1 R}$ : 一様地表面輝度に対するべネチャンブライ ンドのスラット面 1 の輝度の比 [一]

$b_{1 R}, b_{2 R}$ : ベネチャンブラインドのある空面に入射す る地表面反射昼光に対する作業面の下方, 上方に入射寸る光束の割合 $[$ 一 $]$

(25) （27）式で $U_{1 b}, U_{S b}$ の值は文献 7) に示される 方法によって, また, $B_{1 D}, b_{1 D}, b_{2 D}, B_{1 S}, b_{1 S}, b_{2 S}, B_{1 R}$, $b_{1 R}, b_{2 R}$ の值は，完全搪散反射性スラット間で成立する 相互反射の方程式を解くことによって得る。

\section{5. 室内照度の計算例}

計算例として表一1に 示すような室内反射率を 有する図一4のような平 面の南向きの側空室で, 図一5 に示すように空面 の上部に反射ルーバー を，下部にベネチャン ブラインドを設けた場 合 [TYPE I] と空面 全体にベネチャンブラ インドを下ろした場合 [TYPE II] とについ て直射日光率, 天空光 率, 地表面反射昼光率 を求め, さらに天気状 態を想定して室内照度 の試算を行った。

まず，反射ルーバー が図一6 a）に示すよ らな条件のスラットを 有するとして特性值 $L_{1 S}, L_{2 S}, L_{1 R}, L_{2 R}$,
Table 1 Reflectance

\begin{tabular}{rr}
\hline ceiling & 0.70 \\
inner wall & 0.50 \\
floor & 0.20 \\
inner surface & 0.25 \\
of the window & 0.25 \\
\hline
\end{tabular}

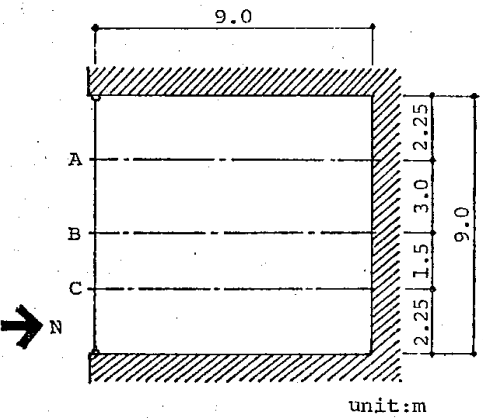

Fig. 4 Plan of the Room

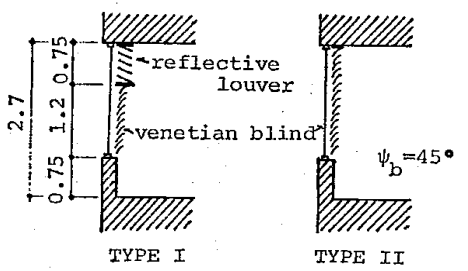

Fig. 5 Window Types 


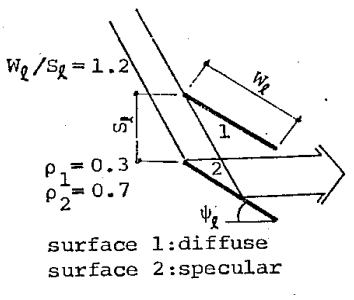

a) reflective louver

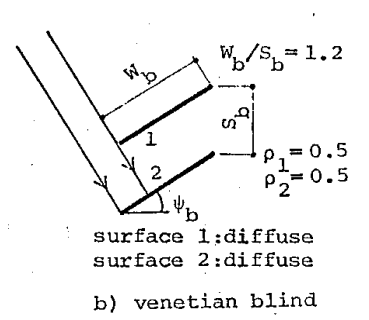

b) venetian blind

Fig. 6 The Condition of Reflective Louver and Venetian Blind

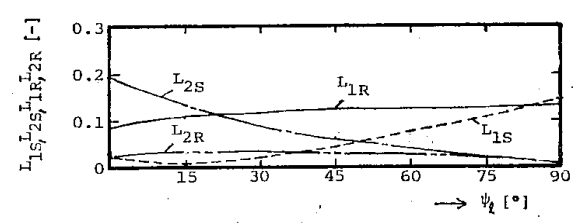

Fig. 7 Relationship between $L_{1 S}, \quad L_{2 S}, \quad L_{1 R}, \quad L_{2 R}$ and Slat Angle $\phi_{l}$

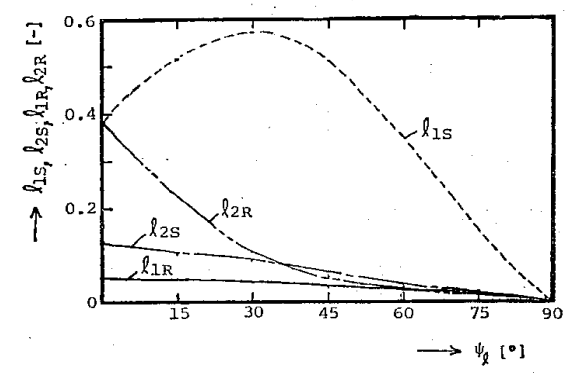

Fig. 8 Relationship between $l_{1 S}, l_{2 S}, l_{1 R}, l_{2 R}$ and Slat Angle $\phi_{l}$

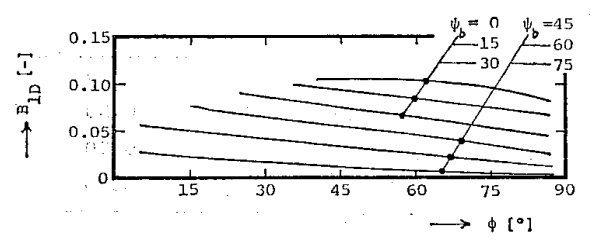

Fig. 9 Relationship between $B_{1 D}$ and Profile Angle $\phi$ with a Parameter Slat Angle $\phi_{b}$

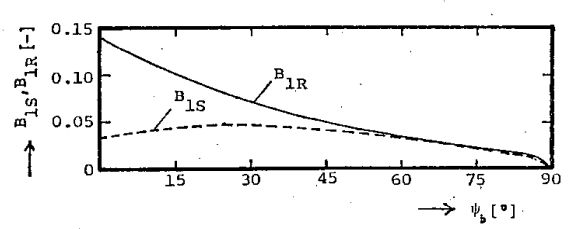

Fig. 10 Relationship between $B_{1 S}$, $B_{1 R}$ and Slat Angle $\phi_{b}$
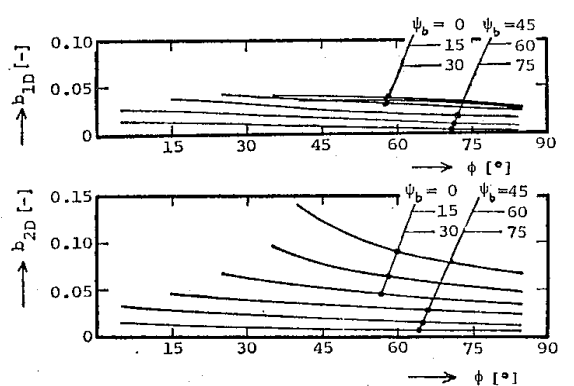

Fig. 11 Relationship between $b_{1 D}, b_{2} D$ and Profile Angle $\phi$ with a Parameter Slat Angle $\phi_{b}$

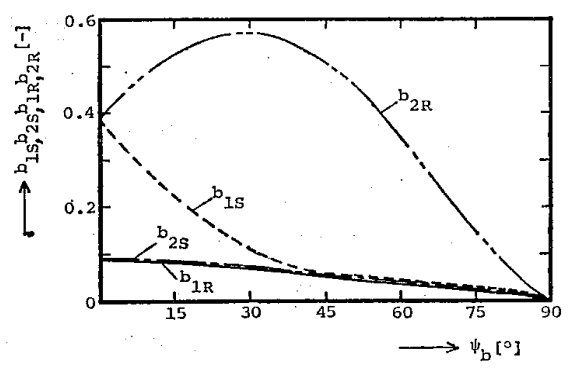

Fig. 12 Relationship between $b_{1 S}, b_{2 S}$, $b_{1 R}, b_{2 R}$ and Slat Angle $\phi_{b}$
(10) 式で定義される $F_{k w}$ の值を 求める必要があるが，これを解析 的に積分するのは困難であるの で，本試算では，代表的な太陽位 置について数值積分した結果とし て表一2 に示寸概略值を用いるこ とにした。

Table 2 Approximate Values of $F_{k w}$

\begin{tabular}{ll}
\hline$F_{1 W}$ & 0.60 \\
$F_{2 W}$ & 0.25 \\
$F_{3 W}$ & 0.25 \\
\hline
\end{tabular}

計算対象室のA列， B列，C列 について直射日光率の値を算出し た結果を図一13 に示す。TYPE Iの場合を参照して明らかなよう に, 10 時には空面に対する太陽方 位角 $r=-41.5^{\circ}$ であるために， $\mathrm{A}$ 列, $\mathrm{B}$ 列, $\mathrm{C}$ 列の直射日光率は それぞれ異なった值をとるが， $=5.1^{\circ}$ となる 12 時には， 3 者と もほぼ同様の值となり，空際と坴 奥の差もあまりなく, 0.02 程度の 值となっている。一方, TYPE II の場合における值射日光率の值は $l_{1 S}, l_{2 S}, l_{1}, l_{2 R}$ を求めた結果を図一7, 図-8 に示す ${ }^{6)}$ 。 ベネチャンブラインドについても図一6 b) に示すよう な条件のスラットであるとして特性值 $B_{1} D, B_{1} S, B_{1 R}$, $b_{1} D, b_{2} D, b_{1}, b_{2 S}, b_{1 R}, b_{2 R}$ を O'Brien の方法 ${ }^{8}$ に準じ て算出した結果を図一9〜図一12 に示す。以下に述べる 試算結果には，図一7〜図-12 に示寸特性值が用いられ ている。なお, 窓ガラスは $3 \mathrm{~mm}$ 普通ガラスとした*1。

*1 商ガラスの透過率 $\tau_{D}, \tau_{d}$ の值は次式加ら算出した。 大射 角党 $\theta$ として

$$
\tau_{D}=r \cdot \sum_{i=1}^{5} a_{i} \cos ^{i} \theta
$$

ここで, $a_{1}=0.95788, \quad a_{2}=9.34036, a_{3}=-27.72065$ $a_{4}=28.44739, a_{5}=-10.12499$ $\tau_{d}=2 \int_{0}^{\pi / 2} \tau_{D} \sin \theta \cos \theta d \theta=0.81 \cdot r$

ただじ, $r$ : 空面積有効率と空ガラス維持率の積 $[-]$ 本試算では， $r=0.72$ を仮定した。
空際で 0.008 前後, 室奥では 0.002 程度であり，直射 日光を利用するために反射ルーバーを設けた TYPE I の場合よりも, 全般的に直射日光率の值は小さくなるこ とがわかる。図-14 は，図一4に示す室の中央点におけ る TYPE II による直射日光率とスラット傾斜角 $\phi_{b}$ 及 びタかけの太陽高度めとの関係を表したものである。図 から明らかなように， $\phi_{b}$ が大きくなり，また， $\phi$ が大き くなるとべネチャンブラインド空面による直射日光率の 值は小さくなる。図一15 は反射ルーバーによる直射日 光率の值を (7) 式に示す精密式から求めた場合と文献 2) に示した簡易式から求めた場合とを，室のA列，B列 について比較したものである。側壁に近いA 列におい て，点線で表される簡易式による直射日光率の值は，壁 面の直射日光受照部の影響を無視しているため $て$ 值が 

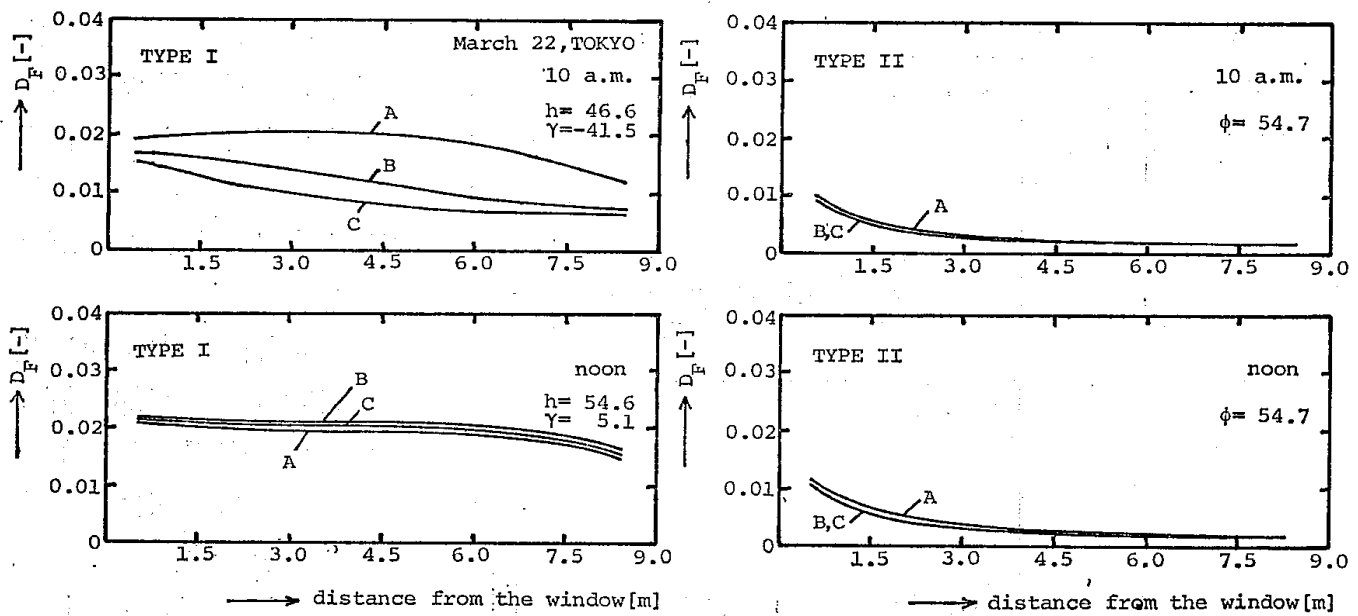

Fig. 13 Distribution of $D_{F}$

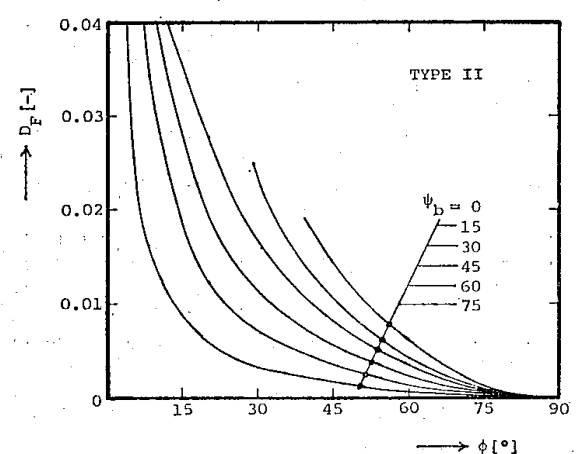

Fig. 14 Relationship between $D_{F}$ at the Point $\mathrm{p}$ on the Work Plane in the case of TYPE II Window and Profile Angle $\phi$
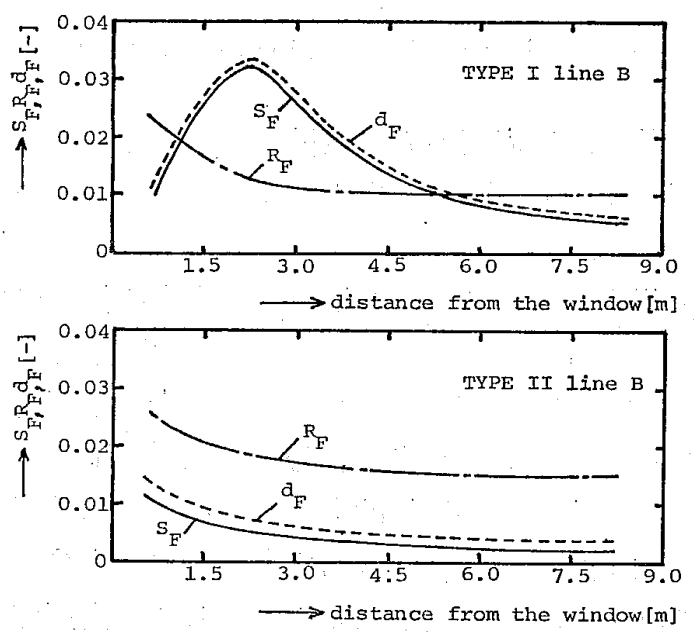

Fig. 16 Distribution of $S_{F}, R_{F}$ and $d_{F}$
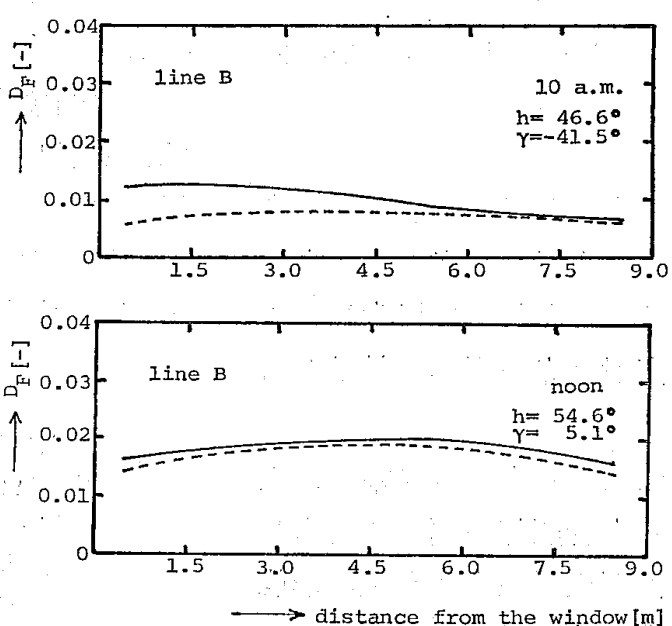

$\rightarrow$ distance from the window $[m]$
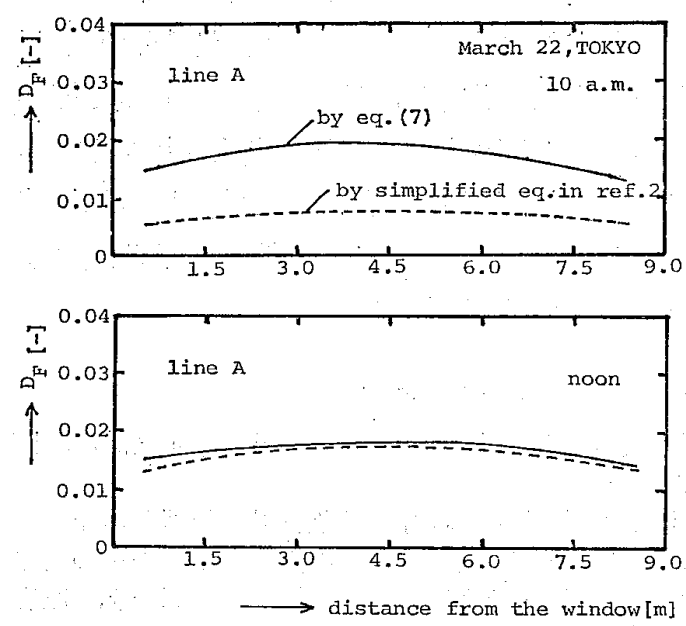

Fig. 15 Distribution of $D_{F}$ by Reflective Louvers Only

比較的大きい 10 時には (7) 式による值の $1 / 2$ 以下にな っている。一方，室のほぼ中央位置するB列では，簡 易式による值射:日光率の值汹 $r=-41.5^{\circ}$ の 10 時でも， 室奥では（7）式による值と誤差 $8 \%$ 程度で一致してい る。 $r=5.1^{\circ}$ である 12 時にはA列でも B列でも (7) 式 と簡易式による直射日光率の值にはほとんど差が見られ ない。
図一16 は, 室の B 列に お㚈る天空光率 $S_{F}$, 地表 面反射昼光率 $R_{F}$ を示した ものである。参考のため に，昼光に対する地表面反 射率 $\rho_{L G}=0.1$ と仮定して (6) 式から昼光率 $d_{F}$ を計 算した結果も図中に示し た。TYPE I による天空 光率 $S_{F}$ の值は, TYPEII によるそれよりも全般的に 大きくなっている。これは 図一5に示したよらに空面 の上部に設けられている反 射ルーバーのスラットが天 空に対して開いているため である。また, TYPE II に よる地表面反射昼光率 $R_{F}$ の值は, 天空光率 $S_{F}$ の值 に比べて 3 5 倍大きくな っている。これは、べネチ ヤンブラインドのスラット が，天空に対しては閉じて いるが，地表面に対しては 開いているためである。 TYPE II による天空光率 $S_{F}$ は, 図一13 に示した直 射日光率 $D_{F}$ と同程度の值 となっている。二年間で屋 外の直射日光照度の值が天 空光照度の値より高くなる 時間数はかなりあるので， 直射日光を積極的に利用し ない昼光照明であっても， 直射日光の室内照度全体に 及ぼす影響は無視し得ない と言える。

10 時に水平面直射日光 照度 $E_{D H}=48200 \mathrm{~lx}$, 水平 面天空光照度 $E_{S H}=27900$ lx, 12 時に $E_{D H}=39600$ $\mathrm{Ix}, E_{S H}=42000 \mathrm{~lx}$ として描いた室B 列の照度分布を図 -17 に示す。TYPE I では, 反射ルーバーがあるため に, 直射白光による室内照度 $E_{P D}$ は室奥でも 500 700 1x となっており，值射日光利用の效果が十分に現れてい る。仮に作業面上の所要照度が $500 \mathrm{~lx}$ とすると, TYPE I では室奥でも $500 \mathrm{~lx}$ を越えているが, TYPE II で は，空際から $2 \mathrm{~m}$ 以上奥では $500 \mathrm{~lx}$ 以下となっている。 

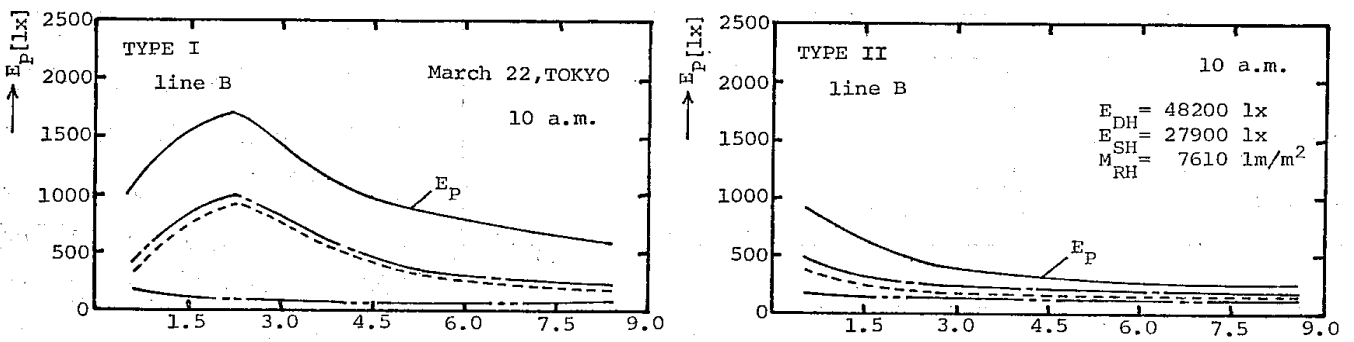

簒囲に設置した場合の室内 照度を訕算した結果，晴天 時には，室奥でも直射日光 を含む昼光によって $500 \mathrm{~lx}$ 程度は確保し得ることがわ かった。
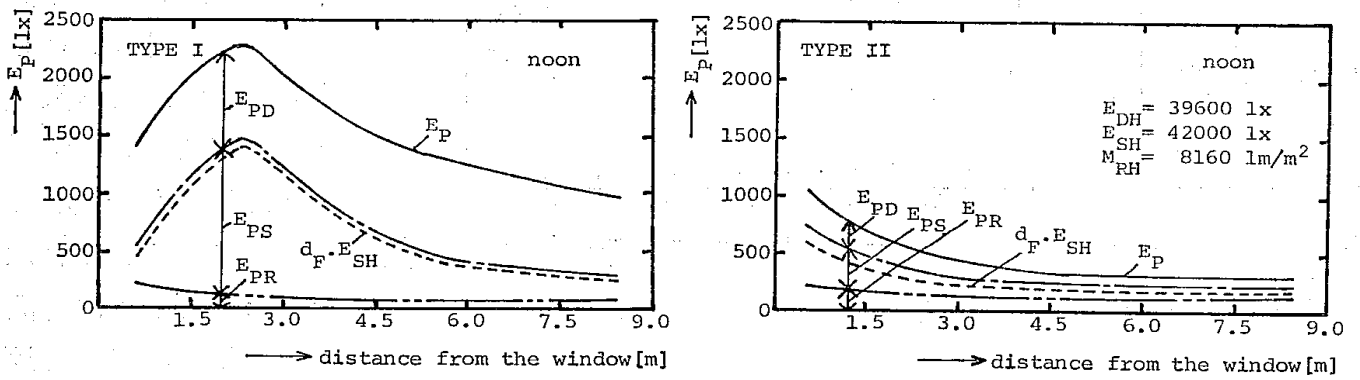

5）天井面, 内壁面に生 ビる直射日光受照部の偏り を考慮して表現した反射ル ーバーのある空面による直 射日光率を, 文献 2) で示 した受照部の偏りを無視し た簡易式による值と比較し た結果，室奥中央では，両

Fig. 17 Distribution of the Total Daylight Illuminance on the Work Plane 者はほぼ一致することがわ かった。したがって，室奥

地表面反射率 $\rho_{L G}=0.1$ とした場合，地表面の光束発散 照度 $M_{R H}$ は，10 時に $7610 \mathrm{~lm} / \mathrm{m}^{2}, 12$ 時に $8160 \mathrm{~lm} /$ $\mathrm{m}^{2}$ となる。 $M_{R H}$ の值は $E_{S H}$ の值の $1 / 3 \sim 1 / 5$ である にもかかわらず，TYPE II の場合に抢ける室奥の地表 面反射昼光による室内照度 $E_{P R}$ は尽光率を用いて求め た室内照度 $\left(d_{F} \cdot E_{S H}\right)$ の 50 80\% の值となって挌り， ベネチャンブラインドのある空面では，直射日光を含む 地表面反射昼光によって得られる室内照度が比較的大き いことがわかる。さらに，值射日光によって得られる室 内照度 $E_{P D}$ は, 地表面反射是光及び天空光による室内 照度の和 $\left(E_{P S}+E_{P R}\right)$ の 50 70\% となっている。こ れらの傾向は，地表面反射率が比較的高いときや屋外の 天空光照度が直射日光に比べてかなり小さい快晴時に はより顕著になるものと考えられる。

\section{6. 結 論}

1）文献 2) に示した直射日光率と昼光率を用いる室 内照度の計算理論を発展させて, 直射日光率, 天空光率 及び地表面反射昼光率を用いることを新たに提案し，こ れによって地表面で反射した直射日光の影響・効果をむ 考慮し得るようにした。

2） 反射ルーバーのある空面による直射日光率を，天 井面及び内壁面に生じる直射日光受照部の偏りを考慮し て表し，また，天空光率，地表面反射昼光率を室の形態 の関数として表示し，その計算方法を示した。

3）直射日光を遮る目的で用いられるべネチャンブラ インドのある密面による直射日光率を。スラットを完全 拡散面の平板と仮定して, みかけの太陽高度及び室の形 態の関数として表した。また，天空光率，地表面反射昼 光率は反射ルーバーと同様に室の形態の関数として表 し，その計算方法を示した。

4) 間口 $9 \mathrm{~m}$, 奥行 $9 \mathrm{~m}$ の南向きの窒で 天井面反射 率を 0.7 として, 反射ルーバーを梥面の上部 $0.75 \mathrm{~m} の$
中央では簡易式の適用が可能である。

6）べネチャンブラインドを空面全体に設置した場合 についての試算を行った結果, 直射日光率の值は, 天空 光率の值とほぼ同様となり，また，地表面反射昼光率の 值は天空光率の $3 \sim 5$ 倍となった。このことから, 直射 日光を積極的に利用しない昼光照明であっても，直射日 光及び地表面反射昼光が室内照度に及ぼす影響を考慮す ることは重要であることが判明した。

7）本論で注面前が十分に開けていることを条件と して室内照度の計算理論を展開したが，対向建物による 影響を考慮する場合にほ，これを地表面反射昼光率に加 味するような形で表すことが必要になると思われる。

8) 本論では, 直射日光率, 天空光率, 地表面反射昼 光率の閒接成分の式は，作業面切断公式を適用して簡易 的に表現したが，壁面閒の相互反射の影響が大きくなる 奥行の深い室では，相互反射を精算して得られる間接成 分の值が大きくなるので，この值と作業面切断公式によ る值を比較検討しておく必要がある。

\section{参考 文 献}

1）日本建築学会設計計画パンフレット 16 : 採光設計, ‘彰国 社, 1963

2）宿谷・木村：直射日光利用の昷光照明の計画とエネルギ 一評洒に関する研究 (その 1. 外側反射ルーバーの効果 について), 日本建築学会論文報告集, 第 283 号, 昭和 54 年 9 月

3）木村・宿谷：直射日光利用に上る昼光照明のエネルギー 評価のための室内照度の表示, 日本建築学会 関東支部研 究報告集, 昭和 55 年 7 月

4) Shukuya, M. \& Kimura, K. : Energy Evaluation of Natural Illumination by Direct Sunlight with Reflective Louvers, 23 28 Angust 1981, Solar World Forum, International Solar Energy Society Congress, Brighton U.K.

5） 木村・宿谷・野原・島村：直射日光利用の自然照明に関 する研究 (その 4. 二次光源の偏りを考慮した直射日光 率について), 日本建築学会大会学術講演梗概集, 昭和 54 
年 9 月

6）木村・售谷・野原 - 島村：直射日光利用の自然照明に関 する研究（その 3 . 反射ルーバーのスラット面平均輝度 及び透過率, 吸収率)，日本建築学会 大会学術講演梗概 集, 昭和 54 年 9 月

7) 松浦：建築照明，共立出版，1971

8) P.F. O'brien : Lighting Calculations for Thirty-Five Thousand Rooms, Illuminating Engineering, April
1960

9) P.F. O'brien : Luminous Flux Transfer In Louvers, Illuminating Engineering, May 1963

10) D.G. Stephenson, G.P. Mitalas : Solar Transmission Through Windows with Venetian Blinds, Proceeding of C.I.E. Sunlight Conference, 1965

11）渡辺 要編：建築計画原諭 $I$, 丸善, 1962

12）木村：建築設備基礎理諭演習, 学献社, 1970

UDC : 628.02

\title{
THEORY ON THE DETERMINATION OF THE WORK PLANE ILLUMINANCE BY DAYLIGHT INCLUDING DIRECT SUNLIGHT THROUGH WINDOWS WITH REFLECTIVE LOUVERS OR VENETIAN BLINDS
}

\author{
By Dr. MASANORI SHUKUYA* and Dr. KEN-ICHI KIMURA**, \\ Members of A.I.J.
}

Daylight factor which has been used to express the work plane illuminance by sky light on cloudy days can not be used to express the total daylight illuminance on the work plane under the clear or partly cloudy sky condition, because it involves no effect of direct sunlight and direct sunlight reflected from the ground. Direct Sunlight Factor $D_{F}$, Sky Light Factor $S_{F}$, and Reflected Daylight Factor $R_{F}$ are proposed to express the work plane illuminance.

$D_{F}, S_{F}$, and $R_{F}$ are defined as follows :

$$
\begin{aligned}
& D_{F}=E_{P D} / E_{D H} \\
& S_{F}=E_{P S} / E_{S H} \\
& R_{F}=E_{P R} / M_{R H}
\end{aligned}
$$

where $E_{P D}, E_{P S}$, and $E_{P R}$ are the work plane illuminances by direct sunlight, sky light, and reflected daylight from the ground, respectively. $E_{D H}, E_{S H}$ are the direct sunlight, sky light illuminance on the horizontal plane outside, respectively. $M_{R H}$ is the luminous emittance of the ground and defined as follows :

$$
M_{R H}=\rho_{L G}\left(E_{D H}+E_{S H}\right)
$$

where $\rho_{L G}$ is the ground reflectance. The concept of $D_{F}, S_{F}$, and $R_{F}$ is shown in Fig 2. Using $D_{F}$, $S_{F}$, and $R_{F}$, the total daylight illuminance on the work plane $E_{P}$ is expressed as follows :

$$
E_{P}=D_{F} \cdot E_{D H}+S_{F} \cdot E_{S H}+R_{F} \cdot M_{R H}
$$

Since $E_{D H}$ is equal to null on totally cloudy days, eq. (5) can be rewritten as follows :

$$
E_{P}=\left(S_{F}+\rho_{L G} \cdot R_{F}\right) E_{S H}=d_{F} \cdot E_{S H}
$$

Eq. (6) shows the relationship among $S_{F}, R_{F}$, the ground reflectance $\rho_{L G}$, and the daylight factor $d_{F}$ conventionally used.

Equations of $D_{F}, S_{F}$, and $R_{F}$ for the case of the reflective louver as an architectural device to use direct sunlight for natural illumination or for the case of the venetian blind set on the window are introduced. $D_{F}$ by the window with reflective louver is expressed as a function of angles of solar incidence to the surfaces of inner walls and ceiling and form factors determined by the shape of the sunlit areas of inner walls and ceiling, whereas $D_{F}$ by the window with the venetian blind as a function of 
profile angle and form factors by the space configuration of the room and the geometry of the slats of the venetian blind. While $S_{F}$ by the window with the reflective louver was expressed as a function of not only normalized luminances of the front and rear surfaces of the louver and their form factors, but also the form factor from the sky viewed from the void space of reflective louvers, $R_{F}$ as a function of the former four variables. $S_{F}$ by the window with the venetian blind was expressed as a function of normalized luminance of the rear surface of the slat and its form factor and the form factor from the sky viewd from the void space of the slats, but $R_{F}$ as a function of the former two variables.

Example calculations of $D_{F}, S_{F}, R_{F}$, and $E_{P}$ along the line $\mathrm{A}, \mathrm{B}$, and $\mathrm{C}$ in the room on the condition of Fig. 3 and Table 1 were made. Two types of the window as shown in Fig. 4 were compared. The conditions of the reflective louver and the venetian blind are shown in Fig. 6 and 9, respectively. Fig. 7, 8, 10 to 13 show their characteristics necessary for calculations of $D_{F}, S_{F}$, and $R_{F}$. Since $D_{F}$ by the window with the reflective louver or venetian blind is a function of solar position, the values of $\dot{D}_{F}$ were computed at $10 \mathrm{am}$ and noon on March 22, Tokyo.

Fig. 14 shows the distribution of $D_{F}$. The value of $D_{F}$ along the line A in the case of TYPE I window at $10 \mathrm{am}$ is larger than that along the line $\mathrm{B}$ or $\mathrm{C}$, because the solar azimuth angle is $-41.5^{\circ}$ and sunlit area on the ceiling surface by the reflective louver becomes irregular. The values of $D_{F}$ along the line $\mathrm{A}, \mathrm{B}$ and $\mathrm{C}$ at noon are, however, almost the same, because the solar azimuth angle is $5^{\circ}$. The values of $D_{F}$ along the line $\mathrm{A}, \mathrm{B}$, and $\mathrm{C}$ for TYPE II window are always quite smaller than those for TYPE I window. Fig. 15 shows the relationship between $D_{F}$ by TYPE II window and profile angle $\phi$ with a parameter of slat angle $\phi_{b}$. The larger the values of $\phi$ and $\phi_{b}$, the smaller that of $D_{F}$. Fig. 16 shows the comparison of $D_{F}$ by the reflective louver calculated using the simplified equation shown in Ref. 2 and elaborate equation (7). In the simplified equation, to neglect the effect of irregularity of the sunlit area is assumed. It turns out that the values of $D_{F}$ along the line $\mathrm{B}$, near the center line, on the work plane far from the window calculated by both equations are approximately equal, even when the solar azimuth angle becomes large.

Fig. 17 shows the distribution of $S_{F}, R_{F}$, and $d_{F}$. The value of $d_{F}$ was calculated assuming the ground reflectance of 0.1 . The value of $S_{F}$ by TYPE I window is larger than that by TYPE II window, because the reflective louver introduces more sky light than the venetian blind does. In the case of TYPE II window, the value of $R_{F}$ is 2 to 5 times larger than that of $S_{F}$, since the venetian blind can introduce reflected daylight from the ground more than sky light. The value of $S_{F}$ in the case of TYPE II window becomes almost the same as that of $D_{F}$ shown in Fig. 14.

The total daylight illuminance on the work plane $E_{P}$ calculated assuming the sunny sky condition on March 22 in Tokyo is shown in Fig. 18. It is made clear that the effect of direct sunlight introduced towards the ceiling by the reflective louver is adequate, because the work plane illuminance by direct sunlight $E_{P D}$ becomes 500 700 lx in the case of TYPE I window. It turns out that $E_{P}$ by TYPE II window indicated as solid line is approximately twice larger than that calculated by conventional daylight factor as broken line. The difference between the work plane illuminances calculated by $D_{F}, S_{F}$, and $R_{F}$ and conventional daylight factor would be more conspicuos under the clearer sky conditions, which would give higher direct sunlight and lower sky light illuminances. It is concluded that the use of direct sunlight fator, sky light factor, and reflected daylight factor is effective to more exactly express the total daylight illuminance on the work plane. The effect of obstructions outside in front of the window might be included in the reflected daylight factor, when it should be considered.

* Post Doctoral Fellow of Science \& Engineering Research Laboratory of Waseda Univ.

** Professor of Waseda Univ. 